Article

\title{
A Clean Process to Prepare High-Quality Acid-Soluble Titanium Slag from Titanium Middling Ore
}

\author{
Jiqing Han ${ }^{1,2}$, Jing Zhang ${ }^{1,2}$, Wei Feng ${ }^{1,2}$, Xiao Chen ${ }^{1,2}$, Li Zhang ${ }^{1,2, *}$ and Ganfeng Tu ${ }^{2}$ \\ 1 Key Laboratory for Ecological Metallurgy of Multimetallic Mineral (Ministry of Education), \\ Northeastern University, Shenyang 110819, China \\ 2 School of Metallurgy, Northeastern University, Shenyang 110819, China \\ * Correspondence: zhangl@smm.neu.edu.cn
}

Received: 27 May 2019; Accepted: 25 July 2019; Published: 27 July 2019

\begin{abstract}
A direct reduction-magnetic separation-alkali leaching-dilute acid washing method was proposed to prepare high-quality acid-soluble titanium slag (HQASTS) from titanium middling ore. The relevant potential $\mathrm{pH}$ diagrams were built, and the analysis results showed that the $\mathrm{pH}$ values for alkali leaching and dilute acid washing should be higher than 13.50 and lower than 1.00, respectively. Increasing temperature was beneficial to alkali leaching but not to dilute acid washing. The effects of operating parameters on the $\mathrm{TiO}_{2}$ content and impurity oxides extraction ratios of titanium slag were investigated, and the optimal experimental conditions were obtained. The HQASTS was obtained with $\mathrm{TiO}_{2}$ and $\mathrm{Fe}_{2} \mathrm{O}_{3}$ content of $75.37 \mathrm{wt} \%$ and $0.96 \mathrm{wt} \%$, respectively, under the above conditions. Furthermore, the leaching mechanism was studied by chemical analysis and X-ray diffraction (XRD) technology, and it was found that the alkali leaching-dilute acid washing process presented in this work could avoid the encapsulation of the unreacted anorthite by the calcium aluminum spinel generated in alkali leaching.
\end{abstract}

Keywords: potential $\mathrm{pH}$ diagram; high-quality acid-soluble titanium slag; titanium middling ore; alkali leaching; dilute acid washing; leaching mechanism

\section{Introduction}

Titanium dioxide pigment has many practical applications, such as paints, plastics, and paper-making plants [1-4]. At present, chloride and sulfate processes serve as the two main commercial strategies in the titanium dioxide industry $[5,6]$. The chloride process, which utilizes rutile as a raw material presently is more favorable economically and generates less waste products; however, sources of natural rutile are limited. Thus, a number of investigations [7-17] (as shown in Table S1 of Supplementary Materials) have been performed to prepare synthetic rutile. The sulfate process that uses ilmenite or acid soluble titanium slag as raw materials is widely applied, but it is lengthy, and ferrous sulfate byproduct is less marketable. These problems are caused by the high content of impurities in the raw materials. It is well known that iron is the most abundant impurity in ilmenite and acid soluble titanium slag and their contents are $\sim 35 \mathrm{wt} \%$ and $\sim 10 \mathrm{wt} \%$, respectively. This part of the iron element eventually enters titaniferous solution in the form of ferrous sulfate. This not only adds the processes of the freezing crystallization and separation of copperas but also produces a large amount of ferrous sulfate. In addition, the high content of ferrous sulfate in titaniferous solution will increase the workload for the purification of metatitanic acid. Thus, it is very meaningful to produce high-quality acid-soluble titanium slag (HQASTS) with low iron content for the sulfate process.

At present, titanium middling ore has been mainly used as the protective material of the blast furnace owing to low $\mathrm{TiO}_{2}$ content $\left(\mathrm{TiO}_{2}<40 \mathrm{wt} \%\right)$, and its comprehensive utilization value is 
relatively low. In order to solve this problem, a method for direct reduction-magnetic separation-alkali leaching-dilute acid $(\mathrm{HCl}$ concentration $\leq 1.29 \mathrm{~mol} / \mathrm{L})$ washing was proposed in this work to prepare the HQASTS, using titanium middling ore as feedstock. The feasibility of the alkali leaching-dilute acid washing process was evaluated by means of thermodynamic analysis. According to the relevant investigations [18-24], binary potential $\mathrm{pH}$ diagrams for $\mathrm{Si}-\mathrm{H}_{2} \mathrm{O}, \mathrm{Al}-\mathrm{H}_{2} \mathrm{O}, \mathrm{Mg}-\mathrm{H}_{2} \mathrm{O}, \mathrm{V}-\mathrm{H}_{2} \mathrm{O}, \mathrm{Ca}-\mathrm{H}_{2} \mathrm{O}$, $\mathrm{Fe}-\mathrm{H}_{2} \mathrm{O}$ and $\mathrm{Mn}-\mathrm{H}_{2} \mathrm{O}$ systems have been reported. It was found that $\mathrm{Al}_{2} \mathrm{O}_{3}, \mathrm{MgO}, \mathrm{V}_{2} \mathrm{O}_{5}, \mathrm{VO}_{2}, \mathrm{CaO}$, $\mathrm{FeO}$ and $\mathrm{MnO}$ could be leached by dilute acid, and $\mathrm{SiO}_{2}$ could be leached by alkali. As titanium slag contains a certain amount of $\mathrm{FeTiO}_{3}, \mathrm{CaTiO}_{3}$, etc., it is necessary to draw ternary potential $\mathrm{pH}$ diagrams for Ca-Ti- $\mathrm{H}_{2} \mathrm{O}$, Fe-Ti- $\mathrm{H}_{2} \mathrm{O}, \mathrm{Mn}-\mathrm{Ti}-\mathrm{H}_{2} \mathrm{O}$ Al-Ti- $\mathrm{H}_{2} \mathrm{O}, \mathrm{Mg}-\mathrm{Ti}^{-} \mathrm{H}_{2} \mathrm{O}$ and $\mathrm{V}-\mathrm{Ti}-\mathrm{H}_{2} \mathrm{O}$ systems. The ternary potential $\mathrm{pH}$ diagram of $\mathrm{Si}-\mathrm{Ti}-\mathrm{H}_{2} \mathrm{O}$ systems cannot be drawn because there are no silicon data in the FactSage software database.

The objective of this study is to prepare high-quality acid-soluble titanium slag by a direct reduction-magnetic separation-alkali leaching-dilute acid washing method and simultaneously realize the comprehensive utilization of titanium middling ore. For optimizing leaching conditions, the effects of operating parameters on $\mathrm{TiO}_{2}$ content and impurity oxides extraction ratios in the titanium slag were investigated. In order to understand the leaching mechanism, the chemical and phase compositions of low-grade titanium slag, the cake after alkali leaching and the cake after alkali leaching-dilute acid washing were determined by chemical analysis and XRD technology.

\section{Materials and Methods}

In this work, titanium middling ore was obtained from the Panzhihua Iron and Steel Research Institute (Sichuan Province, China). The iron element in the titanium middling ore was removed by the pretreatment of the direct reduction-magnetic separation to obtain low-grade titanium slag. The HQASTS from low-grade titanium slag was produced via an alkali leaching-dilute acid washing process.

The content of each element was measured using chemical analysis according to Chinese standards. Such as GB/T 14506.8-2010 for Ti, GB/T 6730.65-2009 for Fe, GB/T 6730.10-2014 for Si etc. The X-ray diffraction (XRD, X' Pert Pro; PANalytical, Almelo, The Netherlands) with $\mathrm{Cu} K \alpha$ radiation $(\lambda=0.154$ $\mathrm{nm}, 40 \mathrm{kV}, 40 \mathrm{~mA}$ ) was employed to characterize the phases. The thermodynamic analysis of the experiment was performed using E-pH module of the FactSage 7.1. Distilled water was used as a solvent throughout the experiment. Other chemical agents used in the present work were provided by China National Medicines Corporation Ltd, Shenyang, China. They are of analytical grade and were used as received. The X-ray diffraction pattern of titanium middling ore is shown in Figure 1. The chemical compositions of titanium middling ore and low-grade titanium slag are listed in Table 1. The schematic diagram of the experimental process is shown in Figure 2.

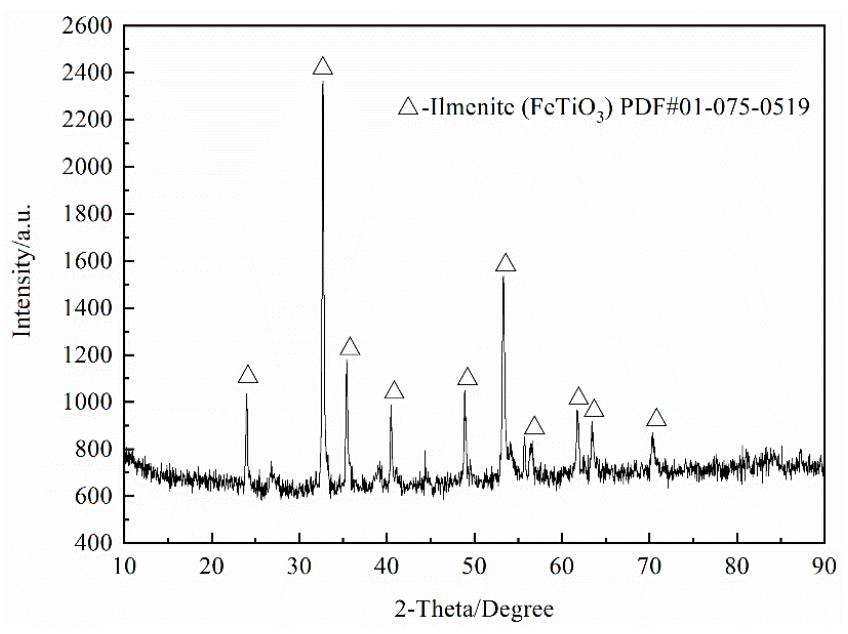

Figure 1. The X-ray diffraction pattern of titanium middling ore. 
Table 1. Chemical compositions of samples (wt \%) (1: titanium middling ore; 2: low-grade titanium slag).

\begin{tabular}{cccccccccc}
\hline Sample & $\mathrm{TiO}_{\mathbf{2}}$ & $\mathrm{Fe}_{\mathbf{2}} \mathbf{O}_{\mathbf{3}}$ & $\mathrm{SiO}_{\mathbf{2}}$ & $\mathbf{C a O}$ & $\mathbf{A l}_{\mathbf{2}} \mathbf{O}_{\mathbf{3}}$ & $\mathbf{V}_{\mathbf{2}} \mathbf{O}_{\mathbf{5}}$ & $\mathbf{M g O}$ & $\mathbf{M n O}$ & $\mathbf{N a}_{\mathbf{2}} \mathbf{O}$ \\
\hline 1 & 37.94 & 38.12 & 9.61 & 5.13 & 3.69 & 2.11 & 1.15 & 0.56 & 0.15 \\
2 & 60.00 & 2.49 & 15.27 & 8.12 & 5.91 & 3.46 & 1.87 & 0.91 & 0.23 \\
\hline
\end{tabular}

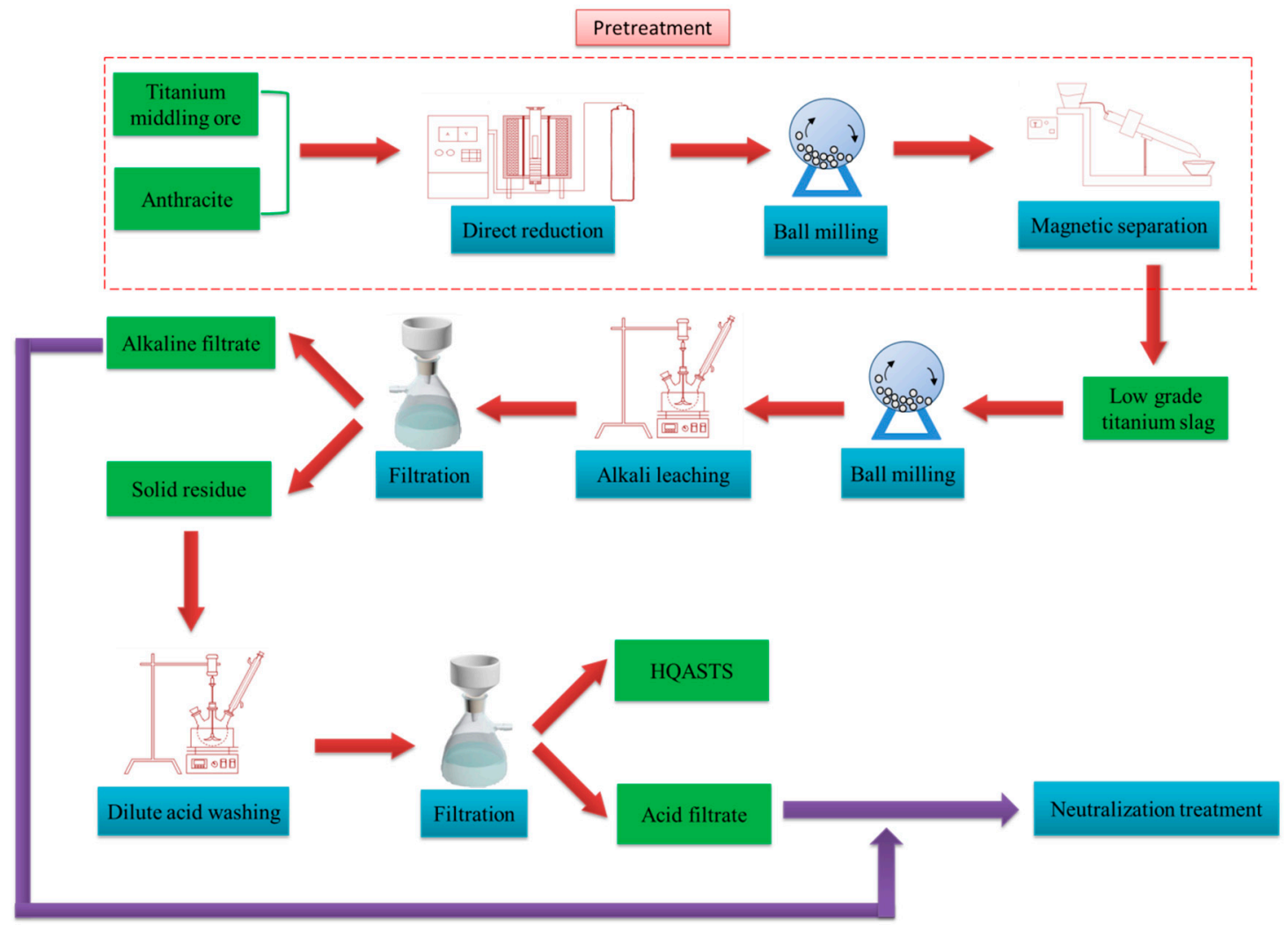

Figure 2. Schematic diagram of the experimental process in the present work. High-quality acid-soluble titanium slag (HQASTS).

As shown in Figure 2, the mixtures (titanium middling ore and $12 \mathrm{wt} \%$ anthracite) were reduced at a temperature of $1350{ }^{\circ} \mathrm{C}$ for $30 \mathrm{~min}$ in a resistance furnace. Next, the reduction product was grinded in a rod mill and then processed through a magnetic separator with a magnetic field intensity of $120 \mathrm{mT}$. The direct reduction and magnetic separation experiments were carried out in a vertical $\mathrm{MoSi}_{2}$ resistance furnace and a Davies Magnetic Tube (CXG- $\Phi 50$, China Tangshan Shida Automation Instrument Technology Co., Ltd, Tangshan, China), respectively.

Before alkali leaching, the low-grade titanium slag was ground to a particle size of less than $48 \mu \mathrm{m}$ and dried in an oven at $110{ }^{\circ} \mathrm{C}$ for $24 \mathrm{~h}$. The leaching experiments were performed at atmospheric pressure in a $500 \mathrm{~mL}$ three-necked flask equipped with a reflux condenser. The reaction mixture was heated by a thermostatic water bath and agitated by a magnetic stirrer at a stirring ratio of $500 \mathrm{rpm}$.

For the alkali leaching process, the amount of titanium slag was fixed at $20 \mathrm{~g}$. According to a certain L/S, the volume of alkali leaching solution can be determined. Then, a known concentration of $\mathrm{NaOH}$ solution was taken and poured into a three-necked flask. Once the specified temperature was reached, titanium slag was added to the reactor and leached for a certain time. At the end of the run, the slurry was filtered to separate the cake from the alkaline solution. The cake was washed with distilled water, dried in an oven at $110{ }^{\circ} \mathrm{C}$ for $24 \mathrm{~h}$, and submitted for chemical analysis.

Before dilute acid washing, titanium slag was first leached under the above optimal alkali leaching conditions. Then, the production of alkali leaching was washed by dilute acid $(\mathrm{HCl})$. The experimental 
procedure is the same as the alkaline leaching experiment. The waste acid and alkaline solutions produced in the process can be treated by neutralization.

\section{Results and Discussion}

\subsection{Thermodynamic Analysis}

To understand the solving behavior of metal elements in the process of alkali leaching-dilute acid washing, ternary potential-pH diagrams were drawn. The results are shown in Figures $3-8$. The molarity concentration used for the calculation is $1 \mathrm{~mol} / \mathrm{L}$.

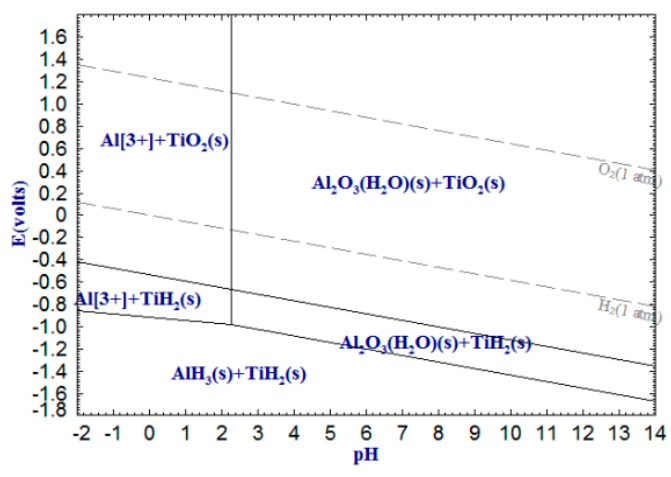

(a)

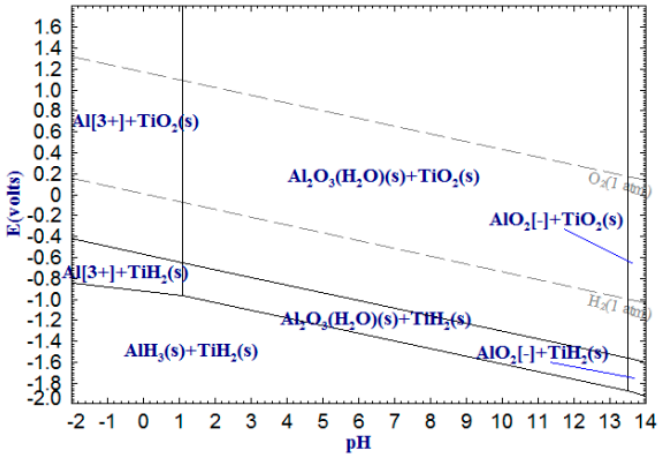

(b)

Figure 3. Potential-pH diagrams for Al-Ti- $\mathrm{H}_{2} \mathrm{O}$ systems: (a) $25^{\circ} \mathrm{C}$; (b) $100{ }^{\circ} \mathrm{C}$.

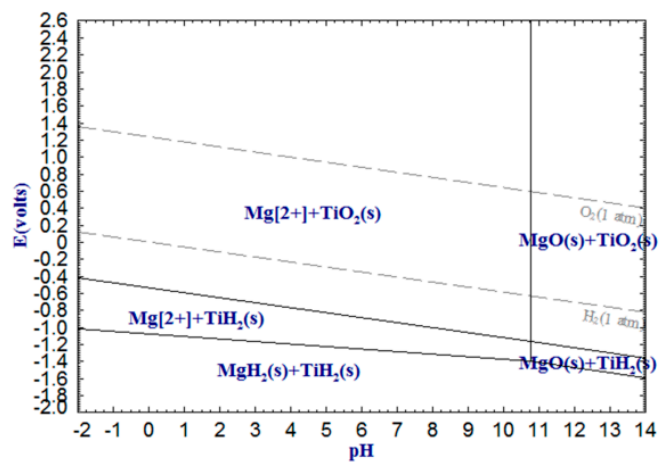

(a)

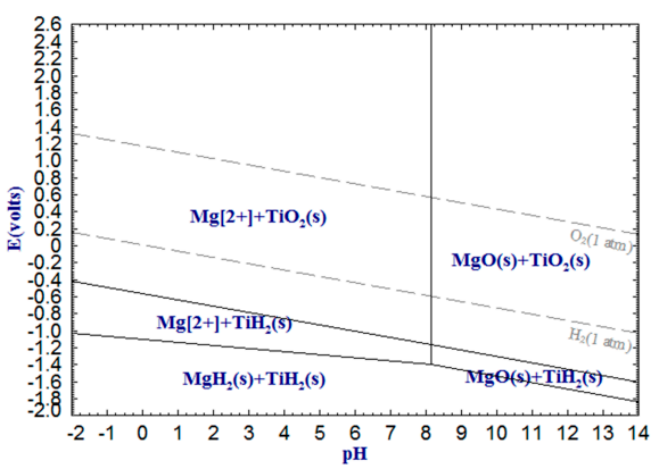

(b)

Figure 4. Potential-pH diagrams for $\mathrm{Mg}-\mathrm{Ti}-\mathrm{H}_{2} \mathrm{O}$ systems: (a) $25^{\circ} \mathrm{C}$; (b) $100{ }^{\circ} \mathrm{C}$.

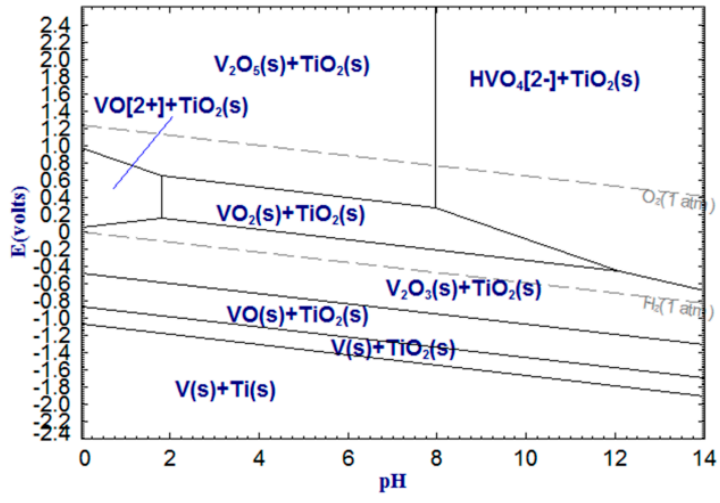

(a)

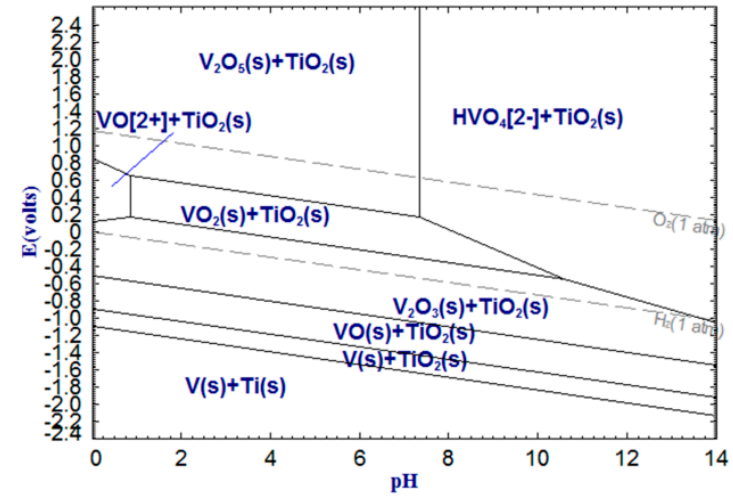

(b)

Figure 5. Potential-pH diagrams for V-Ti- $\mathrm{H}_{2} \mathrm{O}$ systems: (a) $25^{\circ} \mathrm{C}$; (b) $100{ }^{\circ} \mathrm{C}$. 


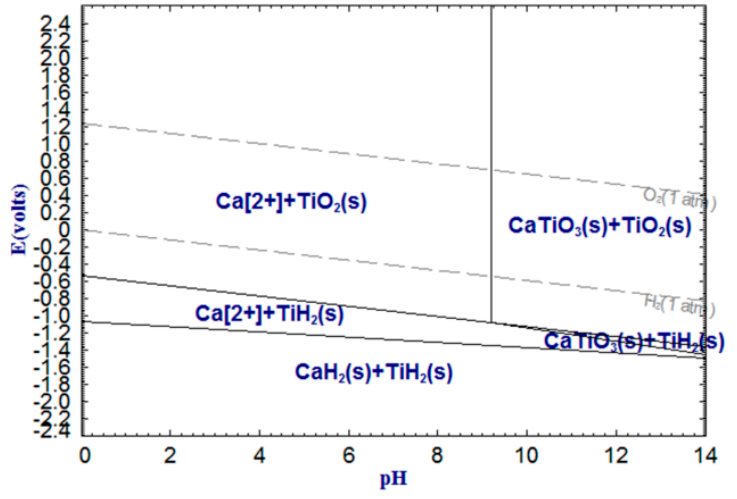

(a)

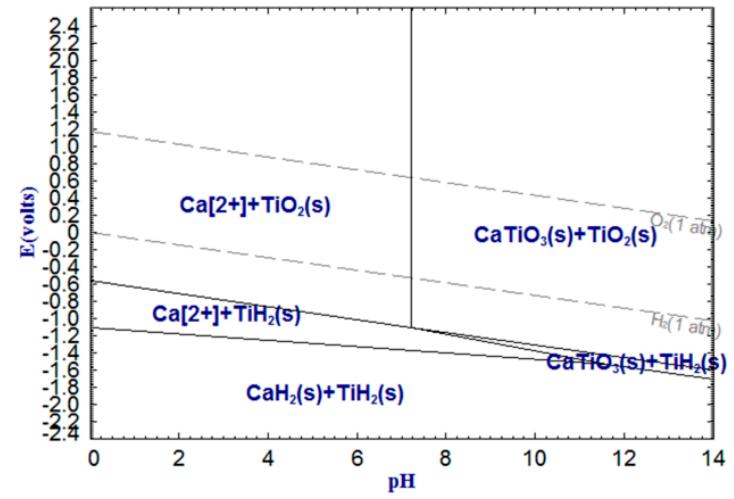

(b)

Figure 6. Potential-pH diagrams for Ca-Ti- $\mathrm{H}_{2} \mathrm{O}$ systems: (a) $25^{\circ} \mathrm{C}$; (b) $100{ }^{\circ} \mathrm{C}$.

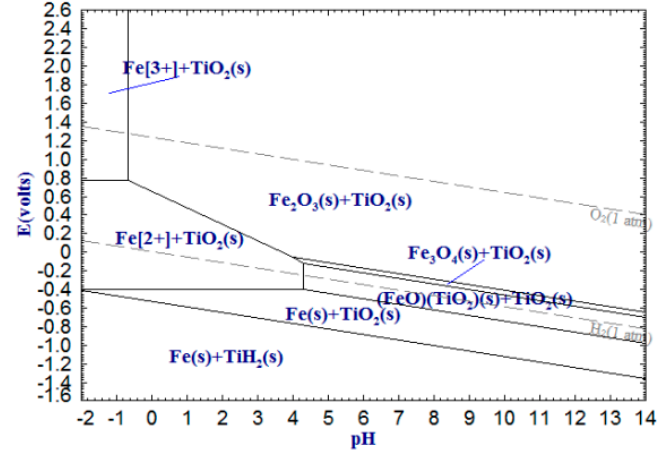

(a)

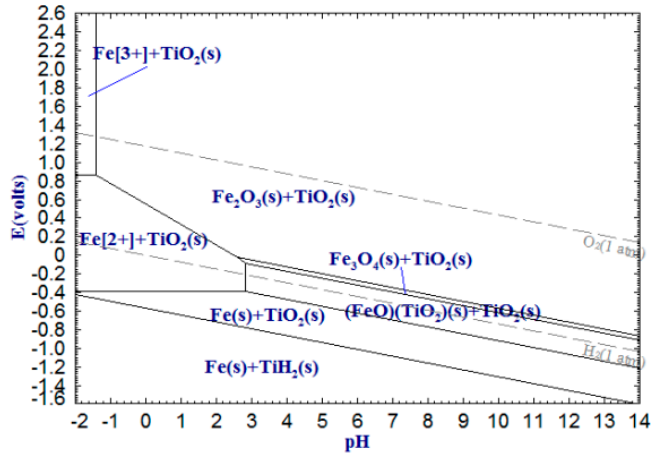

(b)

Figure 7. Potential-pH diagrams for Fe-Ti- $\mathrm{H}_{2} \mathrm{O}$ systems: (a) $25^{\circ} \mathrm{C}$; (b) $100{ }^{\circ} \mathrm{C}$.

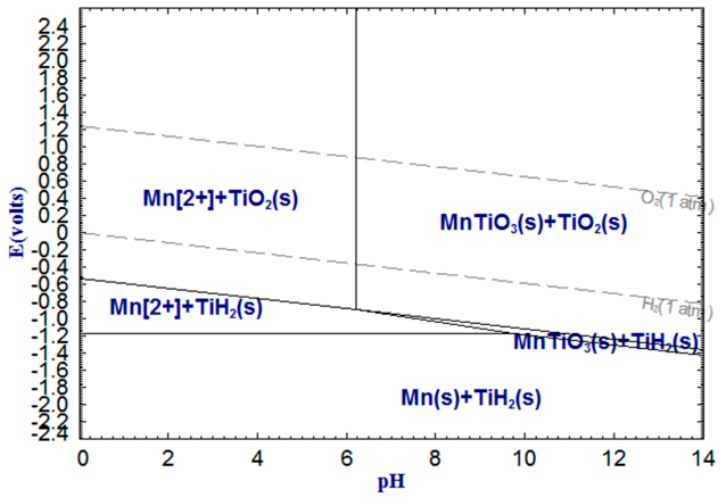

(a)

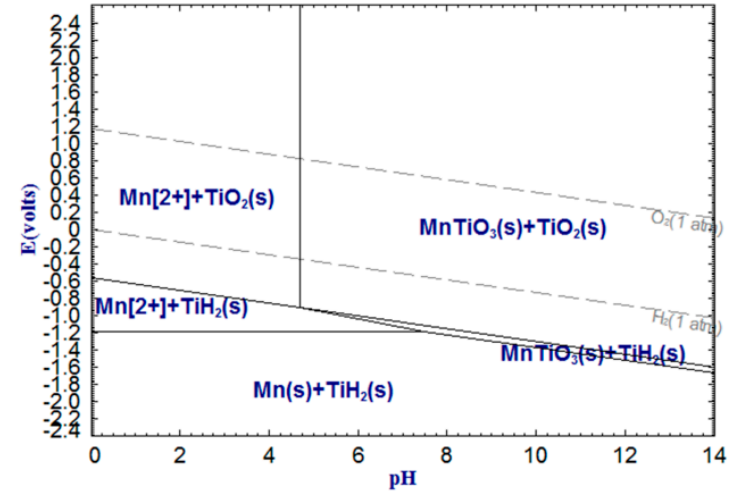

(b)

Figure 8. Potential-pH diagrams for $\mathrm{Mn}-\mathrm{Ti}-\mathrm{H}_{2} \mathrm{O}$ systems: (a) $25^{\circ} \mathrm{C}$; (b) $100{ }^{\circ} \mathrm{C}$.

As can be seen from Figures 3-5, $\mathrm{Al}_{2} \mathrm{O}_{3}, \mathrm{MgO}$ and $\mathrm{VO}_{2}$ in low-grade titanium slag can be removed by dilute acid as $\mathrm{Al}^{3+}, \mathrm{Mg}^{2+}$ and $\mathrm{VO}^{2+}$, respectively, whereas titanium is still present as oxide. When the temperature increases to $100{ }^{\circ} \mathrm{C}, \mathrm{Al}_{2} \mathrm{O}_{3}$ can be leached by alkali with a minimum $\mathrm{pH} 13.50$, indicating that the alkaline leaching of $\mathrm{Al}_{2} \mathrm{O}_{3}$ can be achieved through increasing the temperature. The $\mathrm{V}_{2} \mathrm{O}_{5}$ can also be leached by alkali in the form of $\mathrm{HVO}_{4}^{2-}$, whereas $\mathrm{V}_{2} \mathrm{O}_{3}$ and $\mathrm{VO}$ cannot be leached by acid or alkali. Additionally, as the temperature rises from 25 to $100{ }^{\circ} \mathrm{C}$, the stable areas of $\mathrm{Al}^{3+}, \mathrm{Mg}^{2+} \mathrm{and} \mathrm{VO}^{2+}$ decrease, whereas those $\mathrm{AlO}_{2}^{-}$and $\mathrm{HVO}_{4}^{2-}$ increase, suggesting that increasing temperature not only reduces the required $\mathrm{pH}$ values of the dilute acid washing of $\mathrm{Al}_{2} \mathrm{O}_{3}, \mathrm{MgO}$ and $\mathrm{VO}_{2}$ but also decreases the required $\mathrm{pH}$ values of the alkali leaching of $\mathrm{Al}_{2} \mathrm{O}_{3}$ and $\mathrm{VO}_{5}$. 
As shown in Figures 6-8, $\mathrm{CaTiO}, \mathrm{FeTiO}_{3}$ and $\mathrm{MnTiO}_{3}$ can be removed by dilute acid in the form of $\mathrm{Ca}^{2+}, \mathrm{Fe}^{2+}$ and $\mathrm{Mn}^{2+}$, whereas titanium still exists as oxide. It is worth noting that $\mathrm{Fe}(\mathrm{III})$ cannot be removed by dilute acid due to the not sufficient low $\mathrm{pH}$ of the acid solution. However, $\mathrm{Fe}$ (II) can be more easily removed by dilute acid. Therefore, reducing $\mathrm{Fe}(\mathrm{III})$ into $\mathrm{Fe}(\mathrm{II})$ or metallic iron can significantly enhance the acid solubility of ferrous components in the titanium slag. In addition, with temperature increasing, the stable areas of $\mathrm{Ca}^{2+}, \mathrm{Fe}^{2+}$ and $\mathrm{Mn}^{2+}$ decrease sharply, which means that increasing temperature can reduce the required $\mathrm{pH}$ values of the dilute acid washing of $\mathrm{CaTiO}_{3}, \mathrm{FeTiO}_{3}$ and $\mathrm{MnTiO}_{3}$.

The above analysis indicates that the alkali leaching-dilute acid washing process for upgrading low-grade titanium slag is theoretically feasible. The $\mathrm{pH}$ of the alkali leaching should be higher than 13.50 (Figure 3, Al- $-\mathrm{Ti}-\mathrm{H}_{2} \mathrm{O}, 100^{\circ} \mathrm{C}$ ) and the $\mathrm{pH}$ of the dilute acid washing should be lower than 1.00 (Figure 5, $\mathrm{V}-\mathrm{Ti}-\mathrm{H}_{2} \mathrm{O}, 100{ }^{\circ} \mathrm{C}$ ). A higher temperature is conductive to alkali leaching, but the trend for dilute acid washing is the opposite. Thus, the temperatures for alkali leaching and dilute acid washing can be set at $100^{\circ} \mathrm{C}$ and $25^{\circ} \mathrm{C}$, respectively. This can dramatically decrease the $\mathrm{NaOH}$ concentration of the alkali leaching and the $\mathrm{HCl}$ concentration of the dilute acid washing, which means that a large amount of acid and alkali can be saved.

\subsection{Alkali Leaching}

According to the relevant literature [24] and Figure 3, it can be seen that $\mathrm{SiO}_{2}$ and $\mathrm{Al}_{2} \mathrm{O}_{3}$ in the slag can be theoretically leached by alkali. Thus, the $\mathrm{TiO}_{2}$ content in the slag, $\mathrm{SiO}_{2}$ extraction ratio and $\mathrm{Al}_{2} \mathrm{O}_{3}$ extraction ratio were determined by chemical analysis. The results are shown in Figure 9 . The experimental program of the alkali leaching is provided in Table 2. The $\mathrm{SiO}_{2}(G)$ and $\mathrm{Al}_{2} \mathrm{O}_{3}(H)$ extraction ratios were calculated using the following Equations (1) and (2):

$$
\begin{aligned}
& G=\frac{m_{0} \times w_{G 0}-m_{1} \times w_{G 1}}{m_{0} \times w_{G 0}} \\
& H=\frac{m_{0} \times w_{H 0}-m_{1} \times w_{H 1}}{m_{0} \times w_{H 0}}
\end{aligned}
$$

where $m_{0}$ is the mass of low-grade titanium slag $(20 \mathrm{~g}), m_{1}$ is the mass of the cake after alkali leaching (g), $w_{\mathrm{G} 0}$ and $w_{H 0}$ are the $\mathrm{SiO}_{2}$ and $\mathrm{Al}_{2} \mathrm{O}_{3}$ content, respectively, of low-grade titanium slag (wt \%), and $w_{G 1}$ and $w_{H 1}$ are the $\mathrm{SiO}_{2}$ and $\mathrm{Al}_{2} \mathrm{O}_{3}$ content, respectively, of the cake after alkali leaching (wt \%).

\begin{tabular}{|c|c|c|c|}
\hline No. & Fixed Conditions & Variable & Optimal Value \\
\hline a & $\mathrm{L} / \mathrm{S} 4$, Temperature $55^{\circ} \mathrm{C}$, Time $60 \mathrm{~min}$ & $\begin{array}{c}\mathrm{NaOH} \text { concentration (mol/L): } 1.6,2.2,2.8,3.4, \\
4.1,4.8,5.5,6.3\end{array}$ & 2.8 \\
\hline $\mathrm{b}$ & $\mathrm{NaOH}$ concentration $2.8 \mathrm{~mol} / \mathrm{L}$, Temperature $55^{\circ} \mathrm{C}$, Time $60 \mathrm{~min}$ & $\mathrm{~L} / \mathrm{S}(\mathrm{mL} / \mathrm{g}): 2,4,6,8,10,12,14,16$ & 4 \\
\hline c & $\mathrm{NaOH}$ concentration $2.8 \mathrm{~mol} / \mathrm{L}, \mathrm{L} / \mathrm{S} 4$, Time $60 \mathrm{~min}$ & Temperature $\left({ }^{\circ} \mathrm{C}\right): 25,35,45,55,65,75,85,95$ & 95 \\
\hline $\mathrm{d}$ & $\mathrm{NaOH}$ concentration $2.8 \mathrm{~mol} / \mathrm{L}, \mathrm{L} / \mathrm{S} 4$, Temperature $95^{\circ} \mathrm{C}$ & Time (min): $30,60,90,120,150,180,210,240$ & 60 \\
\hline
\end{tabular}

Table 2. Experimental program of alkali leaching.

The effect of $\mathrm{NaOH}$ concentration on $\mathrm{TiO}_{2}$ content is delineated in Figure 9a. The $\mathrm{TiO}_{2}$ content increased rapidly from 61.62 to $64.58 \mathrm{wt} \%$ as $\mathrm{NaOH}$ concentration increased from 1.6 to $2.8 \mathrm{~mol} / \mathrm{L}$. Within a $\mathrm{NaOH}$ concentration range of $2.8-4.8 \mathrm{~mol} / \mathrm{L}, \mathrm{TiO}_{2}$ content increased slowly. When $\mathrm{NaOH}$ concentration was higher than $4.8 \mathrm{~mol} / \mathrm{L}$, the $\mathrm{TiO}_{2}$ content remained unchanged. Thus, a $\mathrm{NaOH}$ concentration of $2.8 \mathrm{~mol} / \mathrm{L}$ was used in the following experiments. It can be seen that $\mathrm{SiO}_{2}$ in the slag can be leached by alkali and $\mathrm{Al}_{2} \mathrm{O}_{3}$ cannot be removed by alkali under the above conditions. 


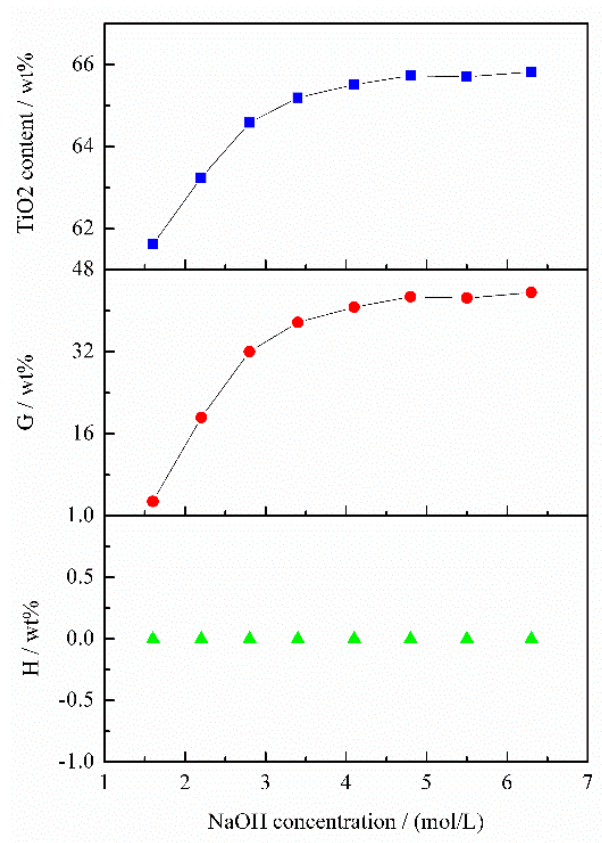

(a)

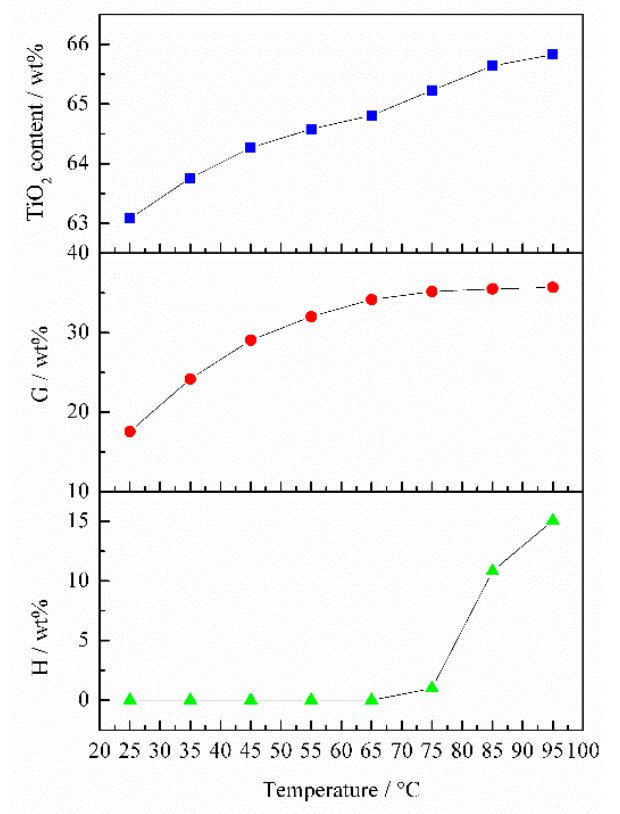

(c)

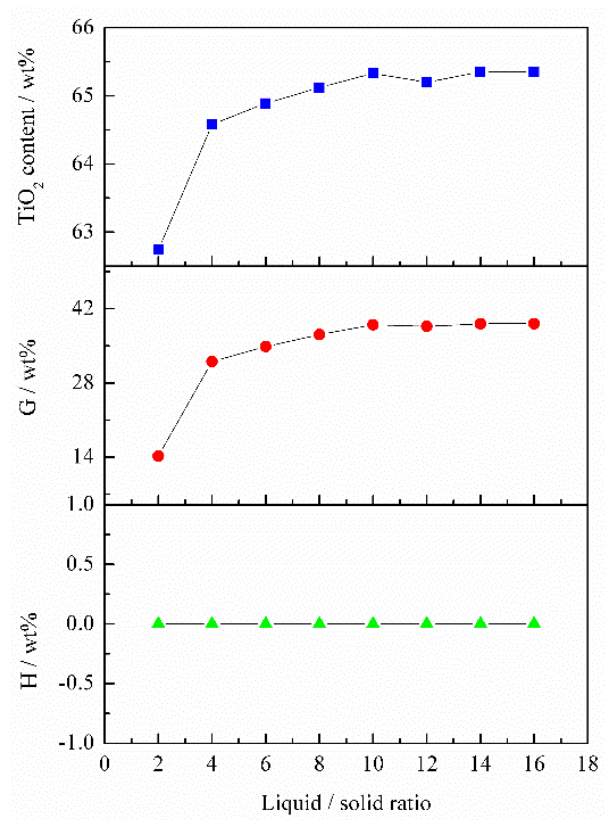

(b)

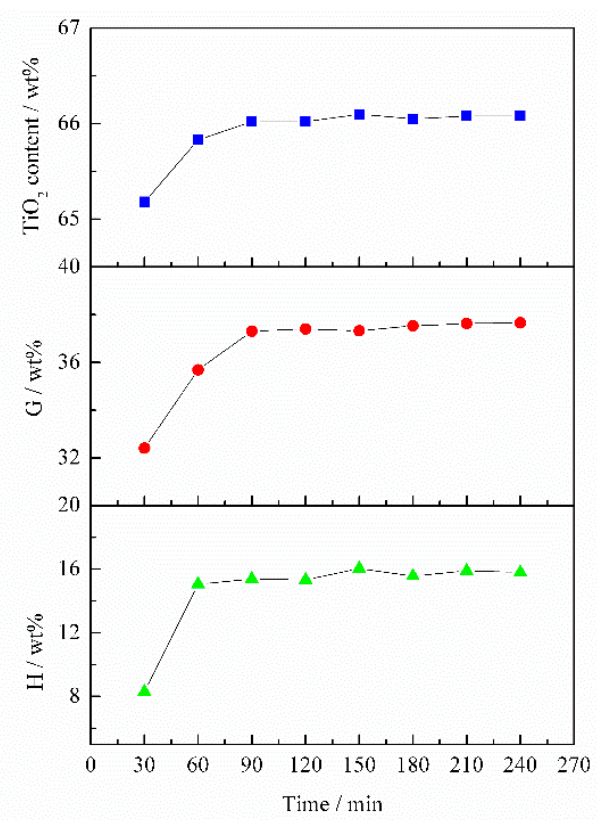

(d)

Figure 9. Effects of $\mathrm{NaOH}$ concentration (a), liquid/solid ratio (b), temperature (c) and time (d) on $\mathrm{TiO}_{2}$ content, $\mathrm{G}\left(\mathrm{SiO}_{2}\right.$ extraction ratio) and $\mathrm{H}\left(\mathrm{Al}_{2} \mathrm{O}_{3}\right.$ extraction ratio).

The effect of liquid/solid ratio (L/S) on $\mathrm{TiO}_{2}$ content is illustrated in Figure $9 \mathrm{~b}$. It was found that $\mathrm{TiO}_{2}$ content increased markedly when $\mathrm{L} / \mathrm{S}$ increased from 2 to 4 . As $\mathrm{L} / \mathrm{S}$ increased from 4 to $10, \mathrm{TiO}_{2}$ content increased insignificantly. At $\mathrm{L} / \mathrm{S}>10, \mathrm{TiO}_{2}$ content remained unchanged. Thus, a $\mathrm{L} / \mathrm{S}$ of 4 was used in subsequent experiments. As shown in Figure $9 \mathrm{~b}$, the variation tendency of $\mathrm{SiO}_{2}$ extraction ratio was consistent with that of $\mathrm{TiO}_{2}$ content, whereas the $\mathrm{Al}_{2} \mathrm{O}_{3}$ extraction ratio remained $0 \mathrm{wt} \%$. This means that only part of $\mathrm{SiO}_{2}$ was leached under the aforementioned conditions.

Figure $9 \mathrm{c}$ shows the effect of temperature on $\mathrm{TiO}_{2}$ content. It is obvious that $\mathrm{TiO}_{2}$ content monotonically increased with the rise in temperature. Therefore, the optimum temperature was $95^{\circ} \mathrm{C}$. When temperature was more than $75^{\circ} \mathrm{C}$, the $\mathrm{SiO}_{2}$ extraction rate remained unchanged, but the $\mathrm{TiO}_{2}$ 
content continued to increase. This is because $\mathrm{Al}_{2} \mathrm{O}_{3}$ started to be leached by a $2.8 \mathrm{~mol} / \mathrm{L} \mathrm{NaOH}$ solution ( $\mathrm{pH} 14.44)$ at $75^{\circ} \mathrm{C}$. This also confirmed the previous conclusion (Figure 3 ) that increasing temperature can achieve the alkali leaching of $\mathrm{Al}_{2} \mathrm{O}_{3}$.

Figure $9 \mathrm{~d}$ illustrates the effect of time on $\mathrm{TiO}_{2}$ content. When time increased from $30 \mathrm{~min}$ to $60 \mathrm{~min}, \mathrm{TiO}_{2}$ content rapidly increased. As time continued to increase to $90 \mathrm{~min}, \mathrm{TiO}_{2}$ content increased slightly. This is because both $\mathrm{SiO}_{2}$ and $\mathrm{Al}_{2} \mathrm{O}_{3}$ can be leached before $30 \mathrm{~min}$, and only a small quantity of $\mathrm{SiO}_{2}$ was leached after $30 \mathrm{~min}$. Hence, the optimum time was $60 \mathrm{~min}$.

Taking the above results into consideration, the optimal alkali-leaching conditions were as follows: $\mathrm{NaOH}$ concentration $2.8 \mathrm{~mol} / \mathrm{L}$ ( $\mathrm{pH} 14.44$ ), $\mathrm{L} / \mathrm{S} 4$, temperature $95^{\circ} \mathrm{C}$ and time $60 \mathrm{~min}$. The $\mathrm{TiO}_{2}$ content of the titanium slag, $\mathrm{SiO}_{2}$ extraction ratio and $\mathrm{Al}_{2} \mathrm{O}_{3}$ extraction ratio were $65.83 \mathrm{wt} \%, 35.69 \mathrm{wt} \%$ and $15.06 \mathrm{wt} \%$, respectively, which indicates single alkali leaching cannot effectively increase $\mathrm{TiO}_{2}$ content in the slag. This may be because $\mathrm{CaAl}_{2} \mathrm{O}_{4}$ (calcium aluminum spinel) produced in the process of alkali leaching covers the surface of unreacted $\mathrm{CaAl}_{2}\left(\mathrm{SiO}_{4}\right)_{2}$ (anorthite) and prevents the reaction between $\mathrm{NaOH}$ and $\mathrm{CaAl}_{2}\left(\mathrm{SiO}_{4}\right)_{2}$. The reliability of potential-pH diagrams for $\mathrm{Al}-\mathrm{Ti}-\mathrm{H}_{2} \mathrm{O}$ systems was confirmed by measuring the $\mathrm{Al}_{2} \mathrm{O}_{3}$ extraction ratio in the slag. Moreover, it was found that the extraction ratio of $\mathrm{Al}_{2} \mathrm{O}_{3}$ is much lower than that of $\mathrm{SiO}_{2}$. As shown in Figure 10, it can be explained by the fact that the standard Gibbs free energy change of chemical reactions (b) is much smaller than that of reaction (a), i.e., $\mathrm{NaOH}$ prefers to react with $\mathrm{SiO}_{2}$ rather than $\mathrm{Al}_{2} \mathrm{O}_{3}$. On the other hand, a small amount of insoluble $\mathrm{NaAl}(\mathrm{OH})_{4}$ was formed during the alkali-leaching process, resulting in a lower extraction rate of $\mathrm{Al}_{2} \mathrm{O}_{3}$. The $\mathrm{NaAl}(\mathrm{OH})_{4}$ content can be determined by the sodium content of the cake after alkali leaching. As shown in Table 4 , the $\mathrm{Na}_{2} \mathrm{O}$ content of the cake increased after alkali leaching. Thus, the main reaction that occurred in the alkali-leaching process is as follows:

$$
\mathrm{CaAl}_{2}\left(\mathrm{SiO}_{4}\right)_{2}+4 \mathrm{NaOH}=\mathrm{CaAl}_{2} \mathrm{O}_{4}+2 \mathrm{Na}_{2} \mathrm{SiO}_{3}+2 \mathrm{H}_{2} \mathrm{O}
$$

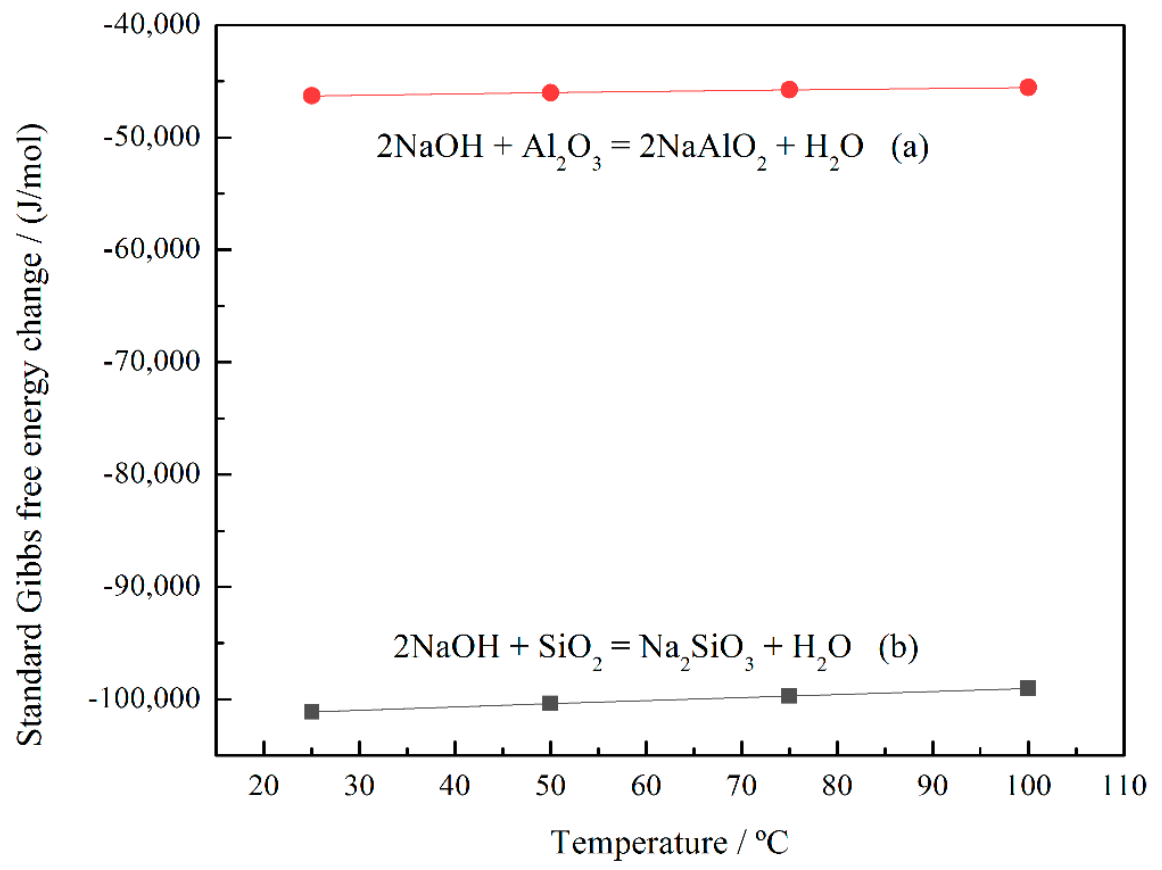

Figure 10. Standard Gibbs free energy change of reactions (a) and (b) at different temperatures.

\subsection{Alkali Leaching-Dilute Acid Washing}

In this work, the low-grade titanium slag was first leached by alkali under the above-mentioned optimal conditions before dilute acid washing. The experimental program of dilute acid washing is shown in Table 3. Based on Figures 3-8, it was observed that $\mathrm{Al}_{2} \mathrm{O}_{3}, \mathrm{MgO}, \mathrm{VO}_{2}, \mathrm{CaO}, \mathrm{FeO}, \mathrm{Fe}$ and $\mathrm{MnO}$ 
in the slag can be theoretically leached by dilute acid. The $\mathrm{MgO}$ and $\mathrm{MnO}$ extraction ratios were not measured because $\mathrm{MgO}$ mainly exists in the form of the anosovite phase, which is insoluble in acid, and the $\mathrm{MnO}$ content is relatively low. Therefore, the $\mathrm{TiO}_{2}$ content in the slag, $\mathrm{CaO}$ extraction ratio, $\mathrm{Al}_{2} \mathrm{O}_{3}$ extraction ratio, $\mathrm{Fe}_{2} \mathrm{O}_{3}$ extraction ratio (the total extraction ratio of various valence iron oxides) and $\mathrm{V}_{2} \mathrm{O}_{5}$ extraction ratio (the total extraction ratio of various valence vanadium oxides) were determined by chemical analysis during the dilute acid washing process. The results are presented in Figure 11. The calculation equations of $\mathrm{CaO}$ extraction ratio $(B), \mathrm{Al}_{2} \mathrm{O}_{3}$ extraction ratio $(C), \mathrm{Fe}_{2} \mathrm{O}_{3}$ extraction ratio $(D)$ and $\mathrm{V}_{2} \mathrm{O}_{5}$ extraction ratio $(E)$ were given in Equations (4), (5), (6) and (7), respectively:

$$
\begin{aligned}
& B=\frac{m_{0} \times w_{B 0}-m_{2} \times w_{B 2}}{m_{0} \times w_{B 0}} \\
& C=\frac{m_{0} \times w_{C 0}-m_{2} \times w_{C 2}}{m_{0} \times w_{C 0}} \\
& D=\frac{m_{0} \times w_{D 0}-m_{2} \times w_{D 2}}{m_{0} \times w_{D 0}} \\
& E=\frac{m_{0} \times w_{E 0}-m_{2} \times w_{E 2}}{m_{0} \times w_{E 0}}
\end{aligned}
$$

where $m_{0}$ is the mass of low-grade titanium slag $(20 \mathrm{~g}), m_{2}$ is the mass of the cake after alkali leaching-dilute acid washing $(\mathrm{g}), w_{B 0}, w_{C 0}, w_{D 0}$ and $w_{E 0}$ are the $\mathrm{CaO}, \mathrm{Al}_{2} \mathrm{O}_{3}, \mathrm{Fe}_{2} \mathrm{O}_{3}$ and $\mathrm{V}_{2} \mathrm{O}_{5}$ content, respectively, of low-grade titanium slag (wt \%) and $w_{B 2}, w_{C 2}, w_{D 2}$ and $w_{E 2}$ are the $\mathrm{CaO}, \mathrm{Al}_{2} \mathrm{O}_{3}, \mathrm{Fe}_{2} \mathrm{O}_{3}$ and $\mathrm{V}_{2} \mathrm{O}_{5}$ content, respectively, of the cake after alkali leaching-dilute acid washing (wt \%).

Table 3. Experimental program of dilute acid washing.

\begin{tabular}{cccc}
\hline No. & Fixed Conditions & Variable & Optimal Value \\
\hline a & L/S 6, Temperature $35{ }^{\circ} \mathrm{C}$, Time $60 \mathrm{~min}$ & $\mathrm{HCl}$ concentration $(\mathrm{mol} / \mathrm{L}): 0.28,0.42,0.56,0.70$, \\
b & $\mathrm{HCl}$ concentration $0.56 \mathrm{~mol} / \mathrm{L}$, Temperature $35^{\circ} \mathrm{C}$, Time $60 \mathrm{~min}$ & $0.85,0.99,1.14,1.29$ & 0.56 \\
$\mathrm{c}$ & $\mathrm{HCl}$ concentration $0.56 \mathrm{~mol} / \mathrm{L}, \mathrm{L} / \mathrm{S} 6$, Time $60 \mathrm{~min}$ & $\mathrm{~L} / \mathrm{S}(\mathrm{mL} / \mathrm{g}): 3,4,5,6,7,8,9,10$ & 6 \\
$\mathrm{~d}$ & $\mathrm{HCl}$ concentration $0.56 \mathrm{~mol} / \mathrm{L}, \mathrm{L} / \mathrm{S} 6$, Temperature $45{ }^{\circ} \mathrm{C}$ & Time $(\mathrm{min}): 30,60,90,120,150,180,210,240$ & 45 \\
\hline
\end{tabular}

The effect of $\mathrm{HCl}$ concentration on $\mathrm{TiO}_{2}$ content is shown in Figure 11a. The $\mathrm{TiO}_{2}$ content sharply increased with $\mathrm{HCl}$ concentration increasing from 0.28 to $0.56 \mathrm{~mol} / \mathrm{L}$. Thereafter, in the $\mathrm{HCl}$ concentration range of $0.56-1.29 \mathrm{~mol} / \mathrm{L}$, the $\mathrm{TiO}_{2}$ content continued to increase at a slow rate. This can be attributed to the fact that $\mathrm{CaO}, \mathrm{Al}_{2} \mathrm{O}_{3}, \mathrm{Fe}_{2} \mathrm{O}_{3}$ and $\mathrm{V}_{2} \mathrm{O}_{5}$ extraction ratios increased significantly as $\mathrm{HCl}$ concentration increased from 0.28 to $0.56 \mathrm{~mol} / \mathrm{L}$, and then these extraction ratios increased slowly when the $\mathrm{HCl}$ concentration was more than $0.56 \mathrm{~mol} / \mathrm{L}$. Taking into account cleaner production and reducing cost, $0.56 \mathrm{~mol} / \mathrm{L} \mathrm{HCl}$ was chosen as the optimum concentration.

The effect of $\mathrm{L} / \mathrm{S}$ on $\mathrm{TiO}_{2}$ content is illustrated in Figure $11 \mathrm{~b}$. The $\mathrm{TiO}_{2}$ content rapidly increased from 71.29 wt \% with $\mathrm{L} / \mathrm{S} 3$ to 73.91 wt \% with $\mathrm{L} / \mathrm{S} 6$. When $\mathrm{L} / \mathrm{S}$ increases from 6 to 8 , the $\mathrm{TiO}_{2}$ content increased slowly. As for the case of $\mathrm{L} / \mathrm{S}>8$, the $\mathrm{TiO}_{2}$ content in the slag was almost constant. It can be explained by the fact that the variation tendencies of $\mathrm{Al}_{2} \mathrm{O}_{3}, \mathrm{CaO}, \mathrm{Fe}_{2} \mathrm{O}_{3}$ and $\mathrm{V}_{2} \mathrm{O}_{5}$ extraction ratios were consistent with that of $\mathrm{TiO}_{2}$ content. Thus, the optimum $\mathrm{L} / \mathrm{S}$ was 6 .

Figure 11c shows the effect of temperature on $\mathrm{TiO}_{2}$ content. The $\mathrm{TiO}_{2}$ content dramatically increased when temperature increased from 25 to $45{ }^{\circ} \mathrm{C}$. Nevertheless, the $\mathrm{TiO}_{2}$ content slightly increased in the temperature range of $45-60^{\circ} \mathrm{C}$. This is because $\mathrm{CaO}, \mathrm{Al}_{2} \mathrm{O}_{3}, \mathrm{Fe}_{2} \mathrm{O}_{3}$ and $\mathrm{V}_{2} \mathrm{O}_{5}$ extraction ratios rapidly increased at $25-45^{\circ} \mathrm{C}$. When temperature was more than $45^{\circ} \mathrm{C}$, the extraction ratio of $\mathrm{Fe}_{2} \mathrm{O}_{3}$ remained unchanged and the extraction ratios of $\mathrm{CaO}$ and $\mathrm{Al}_{2} \mathrm{O}_{3}$ increased at a low ratio. Thus, the optimum temperature was $45^{\circ} \mathrm{C}$.

Figure $11 \mathrm{~d}$ illustrates the effect of time on $\mathrm{TiO}_{2}$ content. The $\mathrm{TiO}_{2}$ content sharply increased as time increased from 30 to $60 \mathrm{~min}$, and then slightly increased with more than 60 min leaching. This is because $\mathrm{CaO}, \mathrm{Al}_{2} \mathrm{O}_{3}, \mathrm{Fe}_{2} \mathrm{O}_{3}$ and $\mathrm{V}_{2} \mathrm{O}_{5}$ can be removed at a high rate as the time increased from 30 to 
$60 \mathrm{~min}$. When the time was longer than $60 \mathrm{~min}$, the $\mathrm{CaO}, \mathrm{Al}_{2} \mathrm{O}_{3}$ and $\mathrm{V}_{2} \mathrm{O}_{5}$ extraction ratios increased slightly and $\mathrm{Fe}_{2} \mathrm{O}_{3}$ extraction rate was almost constant. Hence, the optimum time was $60 \mathrm{~min}$.

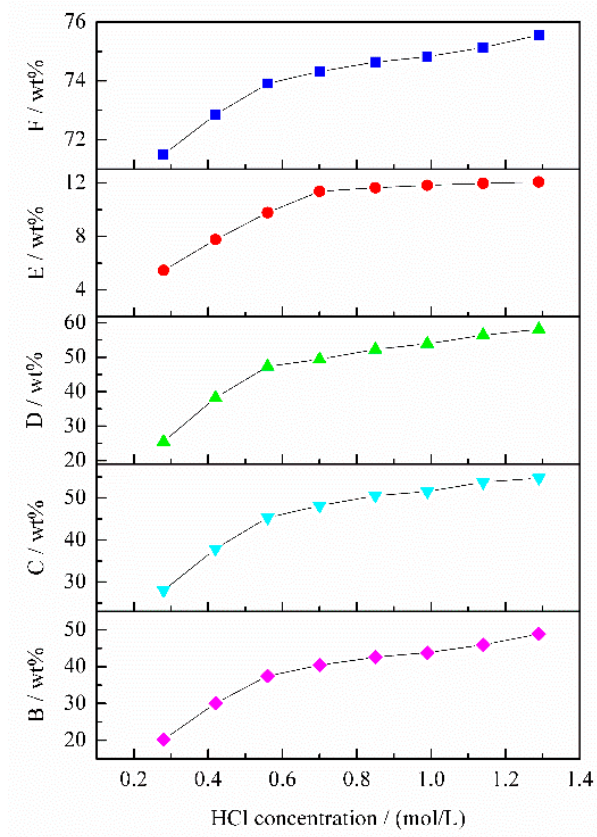

(a)

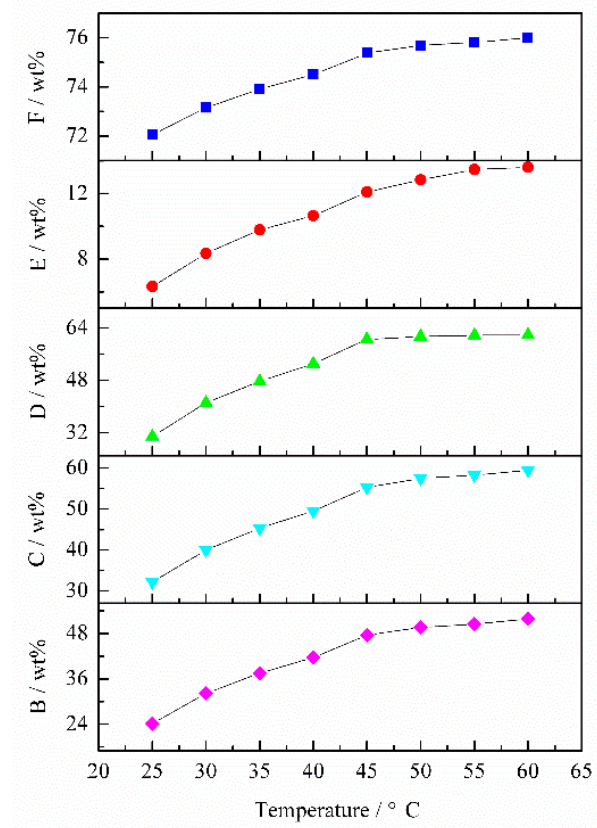

(c)

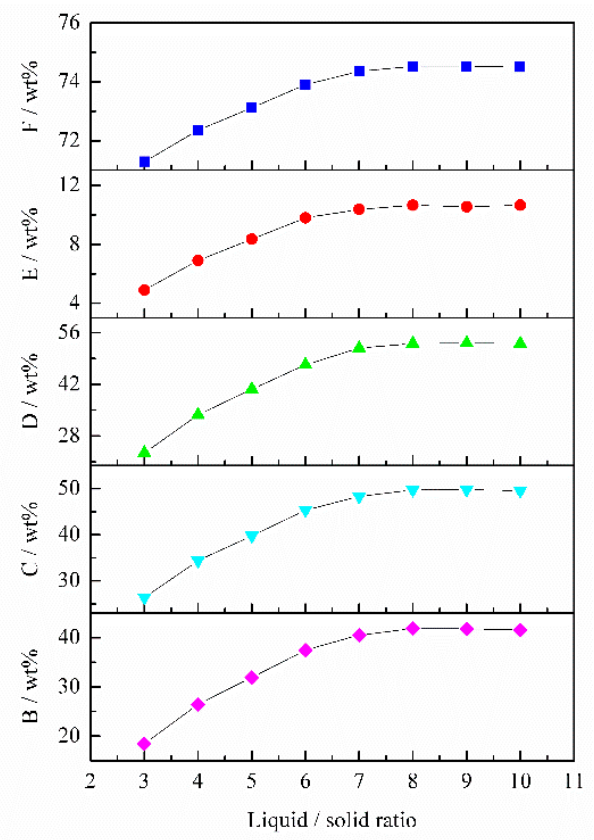

(b)

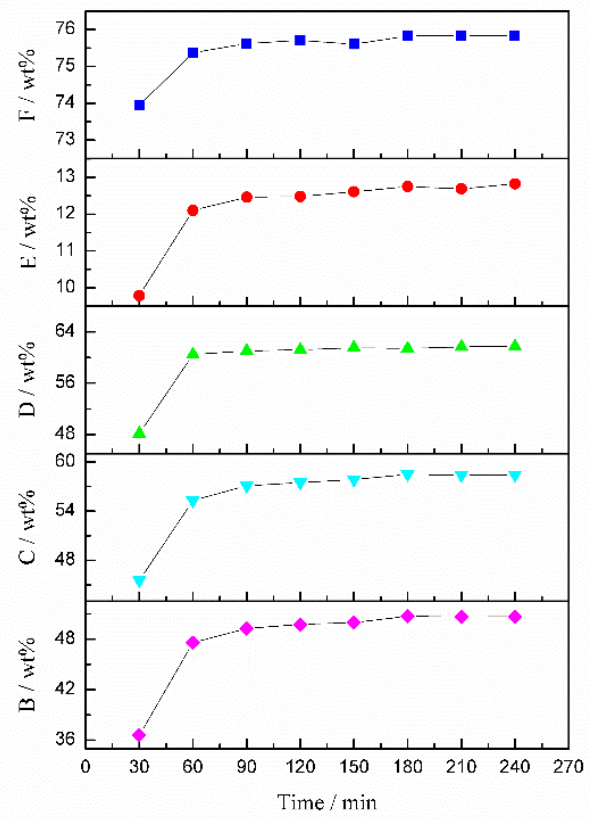

(d)

Figure 11. Effects of dilute acid $(\mathrm{HCl})$ concentration $(\mathbf{a}), \mathrm{L} / \mathrm{S}$ ratio $(\mathbf{b})$, temperature $(\mathbf{c})$ and time $(\mathbf{d})$ on $F$ ( $\mathrm{TiO}_{2}$ content of slag), $E\left(\mathrm{~V}_{2} \mathrm{O}_{5}\right.$ extraction ratio), $D\left(\mathrm{Fe}_{2} \mathrm{O}_{3}\right.$ extraction ratio), $C\left(\mathrm{Al}_{2} \mathrm{O}_{3}\right.$ extraction ratio) and $B$ (CaO extraction ratio).

In summary, the optimal dilute acid washing conditions were $0.56 \mathrm{~mol} / \mathrm{L} \mathrm{HCl}$ concentration $(\mathrm{pH}$ 0.26), $\mathrm{L} / \mathrm{S} 6$, temperature $45{ }^{\circ} \mathrm{C}$ and time $60 \mathrm{~min}$. The $\mathrm{TiO}_{2}$ content of the HQASTS, CaO extraction ratio, $\mathrm{Al}_{2} \mathrm{O}_{3}$ extraction ratio, $\mathrm{Fe}_{2} \mathrm{O}_{3}$ extraction ratio and $\mathrm{V}_{2} \mathrm{O}_{5}$ extraction ratio were 75.37 wt \%, $47.57 \mathrm{wt} \%, 55.33 \mathrm{wt} \%, 60.49 \mathrm{wt} \%$ and $12.10 \mathrm{wt} \%$, respectively; indicating that the process of alkaline leaching-dilute acid washing can significantly improve $\mathrm{TiO}_{2}$ content in titanium-bearing materials. 
In this present study, vanadium oxides in the low-grade titanium slag mainly consist of $\mathrm{V}_{2} \mathrm{O}_{3}$ and a small amount of $\mathrm{VO}_{2}$. It can be seen from Figure 5 that $\mathrm{V}_{2} \mathrm{O}_{3}$ cannot be removed by acid but $\mathrm{VO}_{2}$ can. Therefore, only a small quantity of $\mathrm{VO}_{2}$ was dissolved in acid solution. This is the reason why the $\mathrm{V}_{2} \mathrm{O}_{5}$ extraction rate is only $12.10 \mathrm{wt} \%$. On the other hand, the reliability of potential-pH diagrams $\left(\mathrm{Ca}-\mathrm{Ti}-\mathrm{H}_{2} \mathrm{O}, \mathrm{Al}-\mathrm{Ti}-\mathrm{H}_{2} \mathrm{O}, \mathrm{Fe}-\mathrm{Ti}_{-} \mathrm{H}_{2} \mathrm{O}\right.$ and $\mathrm{V}-\mathrm{Ti}-\mathrm{H}_{2} \mathrm{O}$ ) was confirmed by measuring the $\mathrm{CaO}, \mathrm{Al}_{2} \mathrm{O}_{3}, \mathrm{Fe}_{2} \mathrm{O}_{3}$ and $\mathrm{V}_{2} \mathrm{O}_{5}$ extraction ratios in the slag. In addition, as shown in Figure 11, the variation trends of the $\mathrm{Al}_{2} \mathrm{O}_{3}$ and $\mathrm{CaO}$ extraction ratios under the same conditions were very similar. It can be inferred that $\mathrm{Al}_{2} \mathrm{O}_{3}$ and $\mathrm{CaO}$ were leached in equal proportions. Thus, the main reaction that occurred in the dilute acid washing process is as follows:

$$
\mathrm{CaAl}_{2} \mathrm{O}_{4}+8 \mathrm{HCl}=\mathrm{CaCl}_{2}+2 \mathrm{AlCl}_{3}+4 \mathrm{H}_{2} \mathrm{O}
$$

\subsection{Leaching Mechanism}

In order to gain insight into the leaching mechanism of process, the chemical analysis of resulting solids and solutions as well as XRD test were performed. The results are shown in Tables 4 and 5 and Figure 12.

Table 4. Chemical compositions of residual solids (wt \%) (1: low-grade titanium slag; 2: the cake after optimal alkali leaching; 3: the cake after optimal alkali leaching-dilute acid washing).

\begin{tabular}{cccccccccc}
\hline Sample & $\mathrm{TiO}_{\mathbf{2}}$ & $\mathbf{S i O}_{\mathbf{2}}$ & $\mathbf{C a O}$ & $\mathbf{A l}_{\mathbf{2}} \mathbf{O}_{\mathbf{3}}$ & $\mathbf{V}_{\mathbf{2}} \mathbf{O}_{\mathbf{5}}$ & $\mathrm{Fe}_{\mathbf{2}} \mathbf{O}_{\mathbf{3}}$ & $\mathbf{M g O}$ & $\mathbf{M n O}$ & $\mathbf{N a}_{\mathbf{2}} \mathbf{O}$ \\
\hline 1 & 60.00 & 15.27 & 8.12 & 5.91 & 3.46 & 2.49 & 1.87 & 0.91 & 0.23 \\
2 & 65.83 & 9.82 & 8.24 & 5.02 & 3.47 & 2.43 & 2.01 & 0.95 & 0.95 \\
3 & 75.37 & 8.85 & 4.32 & 2.64 & 3.05 & 0.96 & 2.02 & 0.68 & 0.18 \\
\hline
\end{tabular}

Table 5. Chemical compositions of leaching solutions (g/L) (A: the solution after optimal alkali leaching; B: the solution after optimal dilute acid washing).

\begin{tabular}{ccccccccc}
\hline Sample & Ti & Si & Ca & Al & V & Fe & Mg & Mn \\
\hline A & $<0.1$ & 20.8 & $<0.1$ & 4.0 & $<0.1$ & $<0.1$ & $<0.1$ & $<0.1$ \\
B & $<0.1$ & 0.6 & 6.3 & 3.8 & 0.9 & 2.2 & $<0.1$ & 0.6 \\
\hline
\end{tabular}

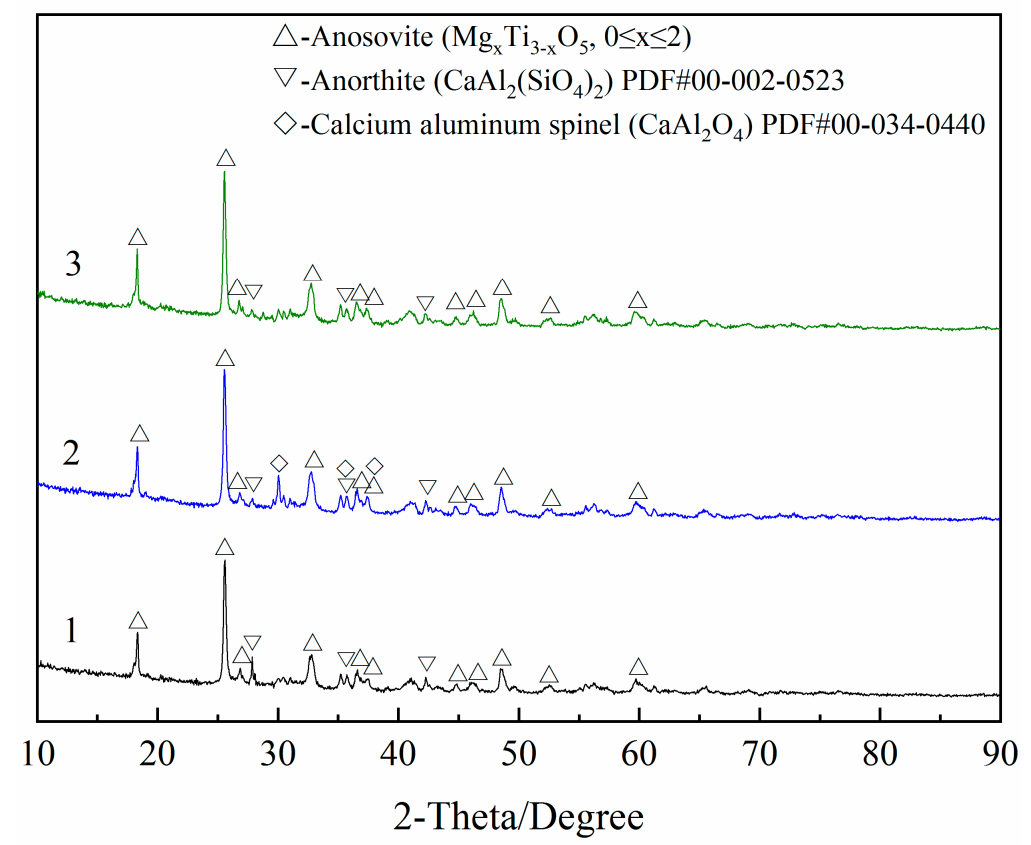

Figure 12. The $X$-ray diffraction $(X R D)$ patterns of residual solids (1: low-grade titanium slag; 2: the cake after optimal alkali leaching; 3: the cake after optimal alkali leaching-dilute acid washing). 
As seen from Tables 4 and 5, more than one-third of $\mathrm{SiO}_{2}$ and a small amount of $\mathrm{Al}_{2} \mathrm{O}_{3}$ were dissolved in an alkaline solution. In the process of dilute acid washing, most of the $\mathrm{Fe}_{2} \mathrm{O}_{3}, \mathrm{Al}_{2} \mathrm{O}_{3}$, $\mathrm{CaO}$ and $\mathrm{MnO}$ and a small quantity of $\mathrm{V}_{2} \mathrm{O}_{5}$ were dissolved in acid solution. The results indicated that the main reactions that occurred in the alkali leaching and dilute acid washing were (3) and (8), respectively. Despite anosovite $\left(\mathrm{Mg}_{\mathrm{x}} \mathrm{Ti}_{3-\mathrm{x}} \mathrm{O}_{5}, 0 \leq \mathrm{x} \leq 2\right)$ phase is insoluble in acid, a small quantity of $\mathrm{MgO}$ must be dissolved because the solid mass decreased during the dilute acid washing process and the $\mathrm{MgO}$ content remained constant. Consequently, the mass of $\mathrm{MgO}$ decreased, indicating that some $\mathrm{MgO}$ exists in other phases. The experimental results are consistent with the previous analysis of potential-pH diagrams and also confirm their authenticity. Moreover, Table 5 shows that the Ti content of alkali and acid solutions is quite low, indicating that almost all Ti components in the slag can be recovered. It is remarkable that the $\mathrm{Fe}_{2} \mathrm{O}_{3}$ content of the HQASTS is only $0.96 \mathrm{wt} \%$. This not only eliminates the processes of the freezing crystallization and separation copperas for sulfate process but also greatly reduces the workload of the subsequent purification of metatitanic acid.

As shown in Figure 12, $\mathrm{CaAl}_{2}\left(\mathrm{SiO}_{4}\right)_{2}$ (anorthite) was transformed into $\mathrm{CaAl}_{2} \mathrm{O}_{4}$ (calcium aluminum spinel) after alkali leaching, and $\mathrm{CaAl}_{2} \mathrm{O}_{4}$ disappeared after dilute acid washing. It was found from experimental results of Sections 3.2 and 3.3 that the main reactions that occurred in the alkali leaching and dilute acid washing were (3) and (8), respectively. The results were consistent with the XRD analysis. In addition, the elemental content changes in Tables 4 and 5 were also in accordance with the $\mathrm{XRD}$ analysis results. Therefore, the leaching mechanism of the process can be represented by Figure 13 . It was observed that $\mathrm{CaAl}_{2} \mathrm{O}_{4}$ generated in alkali leaching, and it encapsulated the unreacted anorthite, causing the sodium hydroxide to not be able to further react with anorthite. This is the main reason for the low content of $\mathrm{TiO}_{2}$ in the slag during the alkali leaching process. Thus, it is not an ideal way to deal with the low-grade Ti-slag by only using alkali leaching. However, $\mathrm{CaAl}_{2} \mathrm{O}_{4}$ can be removed by dilute acid washing. Therefore, the process of alkali leaching-dilute acid washing can avoid the encapsulation of the unreacted anorthite by the calcium aluminum spinel, which is the result of alkali leaching. If an acid leaching-alkali leaching process is employed to upgrade the low-grade titanium slag, silicic acid will be produced during the acid leaching process and encapsulate the unreacted anorthite. Although subsequent alkali leaching can remove the silicic acid, this process wastes a certain amount of the acid and alkali leaching agents. Thus, the alkali leaching-dilute acid washing process is more reasonable.

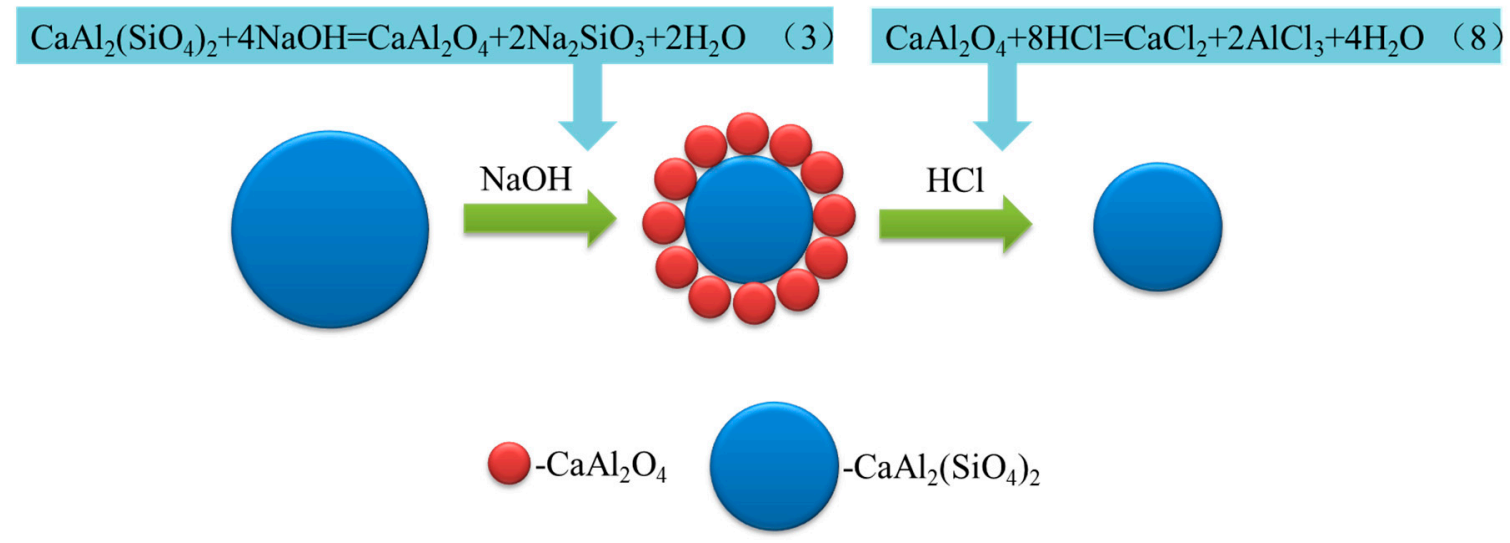

Figure 13. Schematic diagram of leaching mechanism.

\section{Conclusions}

(1) Thermodynamic analysis showed that the $\mathrm{pH}$ of alkali leaching should be higher than 13.50, whereas, that for dilute acid washing should be lower than 1.00. Increasing temperature was beneficial to alkali leaching, but it showed the opposite trend for dilute acid washing.

(2) The optimal alkali leaching conditions were $\mathrm{NaOH}$ concentration $2.8 \mathrm{~mol} / \mathrm{L}(\mathrm{pH} 14.44), \mathrm{L} / \mathrm{S} 4$, temperature $95^{\circ} \mathrm{C}$, time $60 \mathrm{~min}$. The optimal dilute acid washing conditions were $\mathrm{HCl}$ concentration 
$0.56 \mathrm{~mol} / \mathrm{L}$ ( $\mathrm{pH} 0.26$ ), $\mathrm{L} / \mathrm{S} 6$, temperature $45^{\circ} \mathrm{C}$ and time $60 \mathrm{~min}$. Under the above optimum conditions, HQASTS was obtained with $\mathrm{TiO}_{2}$ and $\mathrm{Fe}_{2} \mathrm{O}_{3}$ contents of $75.37 \mathrm{wt} \%$ and $0.96 \mathrm{wt} \%$, respectively.

(3) Applying the HQASTS to the sulfate process can eliminate the processes of the freezing crystallization and separation of copperas, and it can realize the comprehensive utilization of titanium middling ore.

(4) The research of the leaching mechanism indicated that $\mathrm{CaAl}_{2}\left(\mathrm{SiO}_{4}\right)_{2}$ (anorthite) was transformed into $\mathrm{CaAl}_{2} \mathrm{O}_{4}$ (calcium aluminum spinel) after alkali leaching, and $\mathrm{CaAl}_{2} \mathrm{O}_{4}$ disappeared after dilute acid washing. The $\mathrm{CaAl}_{2} \mathrm{O}_{4}$ generated in alkali leaching would encapsulate the unreacted $\mathrm{CaAl}_{2}\left(\mathrm{SiO}_{4}\right)_{2}$, causing the $\mathrm{NaOH}$ to not be able to further react with $\mathrm{CaAl}_{2}\left(\mathrm{SiO}_{4}\right)_{2}$.

Supplementary Materials: The following are available online at http://www.mdpi.com/2075-163X/9/8/460/s1, Table S1: List of the preparation methods of synthetic rutile, Table S2: Verification experiments of predominant species (L/S 4), Figure S1: Effects of $\mathrm{NaOH}$ concentration on $\mathrm{TiO}_{2}$ content at $55^{\circ} \mathrm{C}$ and $95{ }^{\circ} \mathrm{C}$, Figure S2: Effects of $\mathrm{HCl}$ concentration on $\mathrm{TiO}_{2}$ content at $35^{\circ} \mathrm{C}$ and $45^{\circ} \mathrm{C}$, Figure S3: Standard Gibbs free energy change of reactions.

Author Contributions: L.Z. and G.T. designed the experiments; J.H., J.Z., and W.F. conducted the experiments and collected the data; J.H. and X.C. analyzed the data; J.H. wrote the paper.

Funding: This work was supported by Funding Project for National Science and Technology Support Program of China (grant number: 2015BAB18B00).

Conflicts of Interest: The authors declare no conflict of interest.

\section{References}

1. Babaizadeh, H.; Hassan, M. Life cycle assessment of nano-sized titanium dioxide coating on residential windows. Constr. Build. Mater. 2013, 40,314-321. [CrossRef]

2. Gratzel, M. Photoelectrochemical cells. Nature 2001, 414, 338-344. [CrossRef] [PubMed]

3. Yang, W.E.; Hsu, M.L.; Lin, M.C.; Chen, Z.H.; Chen, L.K.; Huang, H.H. Nano/submicron-scale TiO 2 network on titanium surface for dental implant application. J. Alloys Compd. 2009, 479, 642-647. [CrossRef]

4. Yuan, S.A.; Chen, W.H.; Hu, S.S. Fabrication of $\mathrm{TiO}_{2}$ nanoparticles/surfactant polymer complex film on glassy carbon electrode and its application to sensing trace dopamine. Mater. Sci. Eng. 2005, 25, 479-485. [CrossRef]

5. Barksdale, J. Titanium, Its Occurrence, Chemistry, and Technology; Ronald Press Co.: New York, NY, USA, 1949; pp. 23-35.

6. Winkler, J. Titanium Dioxide; Vincentz Verlag: Hannover, Germany, 2003; pp. 71-76.

7. Liu, W.Z.; Lv, L.; Yue, H.R.; Liang, B.; Li, C. Combined production of synthetic rutile in the sulfate $\mathrm{TiO}_{2}$ process. J. Alloys Compd. 2017, 705, 572-580. [CrossRef]

8. Dong, H.G.; Jiang, T.; Guo, Y.F.; Chen, J.L.; Fan, X.X. Upgrading a Ti-slag by a roast-leach process. Hydrometallurgy 2012, 113, 119-121. [CrossRef]

9. Liu, W.Z.; Wang, X.M.; Lu, Z.P.; Yue, H.R.; Liang, B.; Lv, L.; Li, C. Preparation of synthetic rutile via selective sulfation of ilmenite with $\left(\mathrm{NH}_{4}\right)_{2} \mathrm{SO}_{4}$ followed by targeted removal of impurities. Chin. J. Chem. Eng. 2016, 25, 821-828. [CrossRef]

10. Chen, H.F.; Chen, G.; Wu, Y.Q.; Peng, J.H.; Srinivasakannan, C.; Chen, J. Synthesis of Rutile $\mathrm{TiO}_{2}$ from Panzhihua Sulfate Titanium Slag by Microwave Heating. JOM 2017, 69, 2660-2665. [CrossRef]

11. He, A.X.; Chen, G.; Chen, J.; Peng, J.H.; Srinivasakannan, C.; Ruan, R.S. A novel method of synthesis and investigation on transformation of synthetic rutile powders from Panzhihua sulphate titanium slag using microwave heating. Powder Technol. 2018, 323, 115-119. [CrossRef]

12. Zheng, X.Y.; Chen, G.; Chen, J.; Peng, J.H.; Srinivasakannan, C.; Ruan, R.S. Preparation of synthetic rutile from high titanium slag using microwave heating. Phase Transit. 2018, 91, 308-315. [CrossRef]

13. Palliyaguru, L.; Arachchi, N.D.H.; Jayaweera, C.D.; Jayaweera, P.M. Production of synthetic rutile from ilmenite via anion-exchange. Miner. Process. Extr. Metall. 2017, 127, 169-175. [CrossRef]

14. Guo, Y.F.; Liu, S.S.; Jiang, T.; Qiu, G.Z.; Chen, F. A process for producing synthetic rutile from Panzhihua titanium slag. Hydrometallurgy 2014, 147, 134-141. [CrossRef]

15. Lasheen, T.A. Soda ash roasting of titania slag product from Rosetta ilmenite. Hydrometallurgy 2008, 93, 124-128. [CrossRef] 
16. Fan, H.L.; Duan, H.M.; Tan, K.; Li, Y.K.; Chen, D.F.; Long, M.J.; Liu, T. Production of Synthetic Rutile from Molten Titanium Slag with the Addition of $\mathrm{B}_{2} \mathrm{O}_{3}$. JOM 2017, 69, 1914-1919. [CrossRef]

17. Zhang, L.; Li, G.Q.; Sui, Z.T. Study on preparation of titanium-rich material by leaching from modified high titanium slag. In Multipurpose Utilization of Mineral Resources; Electronic Magazines Ltd.: Chengdu, China, 2002; pp. 6-9, (In Chinese with English Abstract).

18. Li, L.; Li, Y.J.; Li, L.; Chen, N.X.; Han, Q.; Zhang, X.Z.; Xu, H. Thermodynamic Analysis on the Coprecipitation of Ni-Co-Mn Hydroxide. Metall. Mater. Trans. 2017, 48, 2743-2750. [CrossRef]

19. Wu, W.Z.; Zhang, T.A.; Dou, Z.H.; Lv, G.Z.; Liu, Y. $\varphi$-pH diagram of V-Ti-H2O system during pressure acid leaching of converter slag containing vanadium and titanium. Trans. Nonferrous Metal Soc. 2011, 21, 2078-2086.

20. Townsend, H.E. Potential-pH diagrams at elevated temperature for the system $\mathrm{Fe}-\mathrm{H}_{2} \mathrm{O}$. Corros. Sci. 1970, 10, 343-358. [CrossRef]

21. Deltombe, E.; Pourbaix, M. The electrochemical behavior of aluminum potential $\mathrm{pH}$ diagram of the System AI- $\mathrm{H}_{2} \mathrm{O}$ at $25^{\circ} \mathrm{C}$. Corrosion 1958, 14, 16-20. [CrossRef]

22. He, H.; Wang, J.; Li, Y.; Song, Z.Y.; Mooni, S. Thermodynamic analysis of hot water leaching of sulphur from desulphurisation slag by E-pH diagrams of the Ca-S- $\mathrm{H}_{2} \mathrm{O}$ system. Miner. Process. Extr. Metall. 2017, 128, 1-7. [CrossRef]

23. Perrault, G.G. The potential-pH diagram of the magnesium-water system. J. Electroanal. Chem. 1974, 51, 107-119. [CrossRef]

24. Zhang, L.; Zhang, J.H.; Zhang, W.; Li, G.Q. Thermodynamic Analysis of Extraction of Synthetic Rutile from Modified Slag. Ind. Eng. Chem. Res. 2013, 52, 4924-4931. [CrossRef]

(C) 2019 by the authors. Licensee MDPI, Basel, Switzerland. This article is an open access article distributed under the terms and conditions of the Creative Commons Attribution (CC BY) license (http://creativecommons.org/licenses/by/4.0/). 